\title{
Cattle Grazing Influence on a Mountain Riparian Zone
}

\author{
LEONARD ROY ROATH AND WILLIAM C. KRUEGER
}

\begin{abstract}
A combination of management and physical topographic constraints caused cattle to concentrate on the riparian zone early in the grazing season in 1977 and 1978. A large percentage of cattle days and vegetation utilization on the riparian zone occurred in the first 4 weeks of the grazing period. Utilization on herbaceous vegetation was 76 and $72 \%$ in 1977 and 1978 , respectively. Impact of grazing on the most prevalent species, Kentucky bluegrass was minimal. Shrub use increased with increased maturity of herbaceous vegetation. Utilization of major shrubs was not excessive in either year, and very likely had no long-term effects on either the abundance or vigor of the shrubs.
\end{abstract}

Riparian zones are those areas associated with streams, lakes, and wet areas where plant communities are predominately influenced by their association with water. They are key areas for a wide variety of uses. Fisheries and wildlife biologists have suggested mountain riparian zones are critical habitats in maintaining viable populations of fish, birds, small and big game animals (Ames 1977, Hubbard 1977). These areas are extremely important in providing forage and water for domestic animals (Phillips 1965, Cook 1966). Watershed specialists have indicated that the riparian zone plays an integral role in water quantity and quality (Horton and Campbell 1977). The U.S. government land management agencies, committed by law to manage for multiple use, have identified riparian zones as critical management areas.

These areas, critical to so many uses, are often subject to great impacts from users. Wildlife and livestock concentrate in these areas, creating a substantial impact on browse and herbaceous vegetation. Recreationists camp, picnic, fish, and hunt along the streams, occassionally inflicting considerable damage on the area. Roads and logging activities can also greatly affect the riparian zone. It becomes apparent that this zone is subject to combined impacts of many activities centered on it. Often the users which are so dependent on a riparian zone are also principal instruments of damage.

Thus, the riparian zone has become a center of attention for range, wildlife, and watershed scientists, conservationists, government agencies, and livestock producers. The result of this is conflict of interest and opinions as to the relative impact of any given activity.

The purposes of this study were to measure the use of herbaceous and woody vegetation on a mountain riparian zone as well as quantify the amount of livestock use on that zone.

Shrubs are often identified as principal vegetation components in considering influences on riparian zones; therefore, considerable emphasis is placed on explaining amount and pattern of shrub use.

\footnotetext{
Authors are graduate student and associate professor, Rangeland Resources Program, Oregon State University, Corvallis 97331 . Roath is now assistant professor, Department of Range Science, Texas A\&M University, College Station 77843; and Krueger is professor, Department of Range Science, Colorado State University, Fort Collins 80523. The authors thank the staff of the Malheur National Forest and ranchers William and Jack Southworth for their cooperation throughout the study.

This article was submitted as Technical Paper No. 5565. Oregon Agricultural Experiment Station, Corvallis. Research was jointly funded by the Oregon Agricultural Experiment Station and Pacific North west Forest and Range Experiment Station. Manuscript received July $18,1980$.
}

The interactions between herbaceous vegetation maturity and availability with shrub utilization will be discussed. The measurements of vegetation use combined with observations were used to develop a qualitative assessment of livestock influences.

\section{Study Area}

The research was conducted on one unit of a U.S. Forest Service allotment in the southern Blue Mountains, approximately $55 \mathrm{~km}$ south of John Day, Oregon. The riparian zone is characterized by seasonally subirrigated Kentucky bluegrass (Poa praetensis) meadows ranging from 20 to $150 \mathrm{~m}$ wide, bordered by steep north and south slopes. This riparian zone extended the full $8.9 \mathrm{~km}$ of the unit and ranged in elevation from 1,440 to $1,545 \mathrm{~m}$. The north slopes are forested with Douglas fir (Pseudotsuga menziesii) where slopes range from 30 to $70 \%$. South slopes are dominated by mountain big sagebrush (Artemisia tridentata ssp. vaseyana) and bluebunch wheatgrass (Agropyron spicatum). The slope on these areas varied from 20 to $60 \%$.

The meadow was subdivided into two types. The dry bluegrass meadow type was characterized by Kentucky bluegrass, junegrass (Koeleria cristata), mountain brome (Bromus marginatus), Columbia needlegrass (Stipa columbiana), and western snowberry (Symphoricarpos occidentalis). The wet meadow type was characterized by Kentucky bluegrass, Baltic rush (Juncus balticus), sedges (Carex spp.), slender wheatgrass (Agropyron trachycaulum), Columbia needlegrass, and numerous forbs including cinquefoil (Potentilla spp.), western yarrow (Achillea millefolium), and pussytoes (Antennaria rosea). In each of the meadow types, bluegrass was by far the most abundant species, comprising $46 \%$ of the vegetation by weight and $65 \%$ of the perennial grasses. Forbs constituted about $24 \%$ of the vegetation composition, while sedges and other grasses comprised 20 and $9 \%$, respectively. Columbia needlegrass and slender wheatgrass combined to form about 1 percent of the vegetation.

A shrub component including mountain alder (Alnus incana), willow (Salix spp.), and red-osier dogwood (Cornus stolonifera) was present near the stream channel. Shrubby cinquefoil (Potentilla fruticosa), twinberry (Lonicera involucrata), and bog birch (Betula glandulosa) occurred occasionally in wet meadows. Currant (Ribes spp.), rose (Rosa woodsii) and mountain silver sagebrush (Artemisia cana spp. viscidula) were interspersed through both meadow types.

\section{Methods}

The procedures for assessing the impact of grazing entailed: (1) intensive sampling of vegetation for vegetation disappearance each week employing the double-sampling technique described by Wilm et al. (1944). This sampling regime employed a $0.25 \mathrm{~m}^{2}$-square frame. Three pace transects of ten plots per transect were examined each week. The transects were spaced evenly, dividing the riparian zone into thirds along the stream course. Plots were randomly located along each transect. A combined regression equation deve- 
loped from two clipped sample plots per transect across all three transects was used for species weight estimate correction. Ten movable cages in 1977 and 15 in 1978 were used to account for vegetation regrowth. (2) Shrub utilization data were obtained by double-sampling procedures from shrubs in five one-tenth ha plots per year. Every shrub within the plot was estimated for leader weight remaining. Five clipped samples per species were used to correct the weight estimates. Percentage available shrub leader removal was estimated for every shrub in the plots as well as $\mathbf{3 0}$ randomly chosen shrubs outside the plot. Weight removal was calculated from weight remaining and utilization data. (3) All cattle were individually marked and cattle numbers and movements were observed on the riparian area. There were nine livestock sampling days in 1977 and 19 sampling days in 1978. (4) Observations were also made on pattern of forage utilization over the grazing season, including order of plant utilization and apparent plant palatability.

The grazing season began on June 29 and June 23, producing a grazing season of 48 and 53 days for 1977 and 1978, respectively, for 250 cows and their calves each year. Crossbred cow-calf pairs, primarily of Hereford, Angus and Shorthorn breeding grazed the area. The grazing season each year corresponded phenologically to anthesis of Kentucky bluegrass. The first season (1977) was drier than usual, causing vegetation to mature earlier, but the following year (1978) had normal precipitation.

Standard analysis of variance and Duncan's new multiple range test were used to test for differences in vegetation weekly disappearance data. Chi-square statistics were used to detect differences in proportion of animal days and vegetation versus proportion of time by period. Additionally, this test was used to compare proportion of animals and proportion of vegetation removal per period. The term significant means ( $P \leq .05$ unless otherwise specified. Statistical procedures follow Steel and Torrie (1960).

\section{Results}

The riparian zone on this unit occupied 44.6 ha, which constituted $1.9 \%$ of the total land area and produced approximately $21 \%$ of available forage on this pasture. Because of livestock concentration, limitations on livestock movements imposed by steep slopes, and er ratic distribution of watering areas away from the creek, the riparian zone accounted for $81 \%$ of the total herbaceous vegetation on the unit removed by livestock in both 1977 and 1978. The utilization of herbaceous vegetation on the riparian zone in 1977 was $76 \%$, which equaled $1,845 \mathrm{~kg} /$ ha vegetation removal (Table 1 ). Utilization in 1978 was $2,089 \mathrm{~kg} /$ ha or $72 \%$ of the available forage. Percentage utilization on perennial grasses was 83 and $75 \%$ for 1977 and 1978, respectively. The average yield of herbaceous vegetation for 1977 was $2,268 \mathrm{~kg}$ / ha compared to $2,795 \mathrm{~kg} / \mathrm{ha}$ in 1978 . The yield difference reflected lower growing season precipitation received in 1977, which was $49 \%$ of 1978 precipitation.

The herbaceous vegetation use, by period, was comparatively large during the first portion of the grazing season (Table 1). There

Table 1. Herbage removal and animal days on the riparian zone for 1977 and 1978.

\begin{tabular}{|c|c|c|c|c|c|c|}
\hline & \multicolumn{2}{|c|}{ Time grazed } & \multicolumn{2}{|c|}{ Herbage removal } & \multicolumn{2}{|c|}{ Animal days } \\
\hline & wks & $\%$ & kg/ha & $\%$ & numbers & $\%$ \\
\hline \multirow[t]{2}{*}{1977} & $\begin{array}{l}3.7 \\
1.0 \\
1.0 \\
1.0 \\
\end{array}$ & $\begin{array}{l}55 \\
15 \\
15 \\
15\end{array}$ & $\begin{array}{r}1539 \\
64 \\
117 \\
125 \\
\end{array}$ & $\begin{array}{r}83 \\
12 \\
4 \\
4\end{array}$ & $\begin{array}{r}3696 \\
651 \\
466 \\
538 \\
\end{array}$ & $\begin{array}{r}69 \\
12 \\
9 \\
10\end{array}$ \\
\hline & 6.7 & & 1845 & & 5351 & \\
\hline \multirow[t]{2}{*}{1978} & $\begin{array}{l}4.7 \\
1.0 \\
1.0 \\
1.0 \\
\end{array}$ & $\begin{array}{l}61 \\
13 \\
13 \\
13\end{array}$ & $\begin{array}{r}1757 \\
247 \\
85 \\
0 \\
\end{array}$ & $\begin{array}{r}84 \\
12 \\
4 \\
4\end{array}$ & $\begin{array}{r}4448 \\
609 \\
623 \\
825 \\
\end{array}$ & $\begin{array}{l}69 \\
12 \\
10 \\
12\end{array}$ \\
\hline & 7.7 & & 2089 & & 6485 & \\
\hline
\end{tabular}

Table 2. Herbage removal and animal days per week on the riparian zone for 1977 and 1978.

\begin{tabular}{|c|c|c|c|c|}
\hline & \multicolumn{2}{|c|}{ Herbage removal/wk } & \multicolumn{2}{|c|}{ Animal days/wk } \\
\hline & $\mathrm{kg} / \mathrm{ha}$ & $\%$ & number & $\%$ \\
\hline 1977 & $\begin{array}{c}416 \mathrm{a}^{\mathrm{t}} \\
64 \mathrm{~b} \\
117 \mathrm{~b} \\
125 \mathrm{~b}\end{array}$ & $\begin{array}{r}22 \\
4 \\
6 \\
7\end{array}$ & $\begin{array}{l}999 \\
651 \\
466 \\
538\end{array}$ & $\begin{array}{r}19 \\
12 \\
9 \\
10\end{array}$ \\
\hline 1978 & $\begin{array}{r}374 a \\
247 b \\
85 c \\
0 c\end{array}$ & $\begin{array}{r}18 \\
12 \\
4 \\
-\end{array}$ & $\begin{array}{l}946 \\
609 \\
623 \\
825\end{array}$ & $\begin{array}{l}15 \\
12 \\
10 \\
12\end{array}$ \\
\hline
\end{tabular}

'Values within years for $\mathrm{kg} / \mathrm{ha}$ per week designated with different letters are significantly different, $P \leq .05$.

was also a trend of progressively smaller amounts of vegetation removal as the grazing season progressed. Significantly more utilization per week (Table 2) occurred during the first grazing period than any other period. During the last 3 weeks of 1977 and the last 2 weeks of 1978, no significant vegetation use on the riparian zone could be resolved even though animal days increased. Use on the adjacent vegetation types became more prevalent during the last 2 weeks for both years. The steep south slope type bordering the riparian zone was most used during this time.

Shrub use on the riparian zone was different in 1977 compared to 1978 (Table 3). Average utilization of leaders was significantly greater in 1977 than in 1978 for willow, currant, rose, and snowberry. Utilization on alder was not significantly different between years. High degrees of utilization on leaders were also prevalent on twinberry and bog birch in 1977; however, insufficient samples were taken to test the difference between years.

The total utilization of available shrubs on a weight basis was $48 \%$ in 1977 and $31 \%$ in 1978 for all species combined. Willows provided $37 \%$ of the shrub weight used on the area in 1977 , but accounted for only $27 \%$ of the total shrubs available. Twinberry appeared to be used greatly in excess of its percentage availability. Rose, snowberry, and currant combined were used comparable to their percentage presence. These species had $15 \%$ of the weight use

Table 3. Percentage shrub utilization and weight removal for 1977 and 1978.

\begin{tabular}{|c|c|c|c|c|c|}
\hline \multirow{2}{*}{$\frac{\text { Shrub }}{1977}$} & \multicolumn{2}{|c|}{ Area occupied } & \multirow{2}{*}{$\begin{array}{l}\% \text { avail. } \\
\text { wt. }\end{array}$} & \multirow{2}{*}{$\begin{array}{l}\text { \% leader } \\
\text { util }\end{array}$} & \multirow{2}{*}{$\begin{array}{l}\% \text { wt. } \\
\text { removed }\end{array}$} \\
\hline & $\mathrm{Ha}$ & $\%$ area & & & \\
\hline Alder & 9.8 & 72 & 57 & 39 & 47 \\
\hline Willow & 1.6 & 12 & 27 & 64 & 37 \\
\hline Rose & & & & 34 & \\
\hline Currant & 1.2 & 9 & 14 & 57 & 15 \\
\hline Snowberry & & & & 53 & \\
\hline Dogwood & 0.2 & 2 & $\mathbf{I}$ & 61 & $\mathbf{T}$ \\
\hline Bog birch & 0.6 & 4 & $\mathrm{~T}$ & 48 & 1 \\
\hline Twinberry & 0.05 & - & $\mathrm{T}$ & 75 & $\mathrm{~T}$ \\
\hline \multirow{3}{*}{$\begin{array}{l}\text { Shrubby } \\
\text { cinquefoil }\end{array}$} & & & & & \\
\hline & 0.15 & 1 & $\mathbf{T}$ & 21 & $\mathbf{T}$ \\
\hline & 13.60 & & & & \\
\hline \multicolumn{6}{|l|}{1978} \\
\hline Alder & 9.8 & 72 & 61 & 28 & 51 \\
\hline Willow & 1.6 & 12 & 20 & 54 & 33 \\
\hline Rose & & & & 8 & \\
\hline Currant $\}$ & 1.2 & 9 & 12 & 32 & 11 \\
\hline Snowberry & & & & 20 & \\
\hline Dogwood & 0.2 & 2 & & $\mathbf{T}$ & \\
\hline Bog birch & 0.6 & 4 & 6 & 28 & 5 \\
\hline Twinberry & 0.05 & - & $\mathbf{T}$ & 44 & $\mathbf{T}$ \\
\hline \multirow{3}{*}{$\begin{array}{l}\text { Shrubby } \\
\text { cinquefoil }\end{array}$} & & & & & \\
\hline & 0.15 & 1 & & 0 & \\
\hline & 13.60 & & & & \\
\hline
\end{tabular}


and comprised $14 \%$ of the shrubs available. Alder, on the other hand, was not preferred, providing $57 \%$ of the available shrub production but only 47 percent of the total use on shrubs. The 1978 weight utilization had the same trend found in 1977, but at lower levels. The pattern of shrub utilization was different between years. In 1977, utilization was initiated at the time when cattle came into the unit and was progressive throughout the season. This was a year of low precipitation and rapidly advancing herbaceous vegetation maturity when the cattle began grazing. Additionally, herbaceous forage production was low (Table 1). Willow was utilized in excess of its percentage availability. Rose, snowberry, and currant use was approximately the same as availability. The only shrubs which were obviously avoided by livestock were shrubby cinquefoil and mountain silver sagebrush.

In 1978 (a normal precipitation year), shrub utilization during the early portions of the grazing season was low. Even preferred species were used very little during the first 4 weeks of the grazing season. When shrub utilization began, more selectivity was demonstrated than in 1977. Willow and currant received the most use at that time. Alder was not used until later in the season. Species such as dogwood and rose, which had received considerable use in 1977 , received little or no use in 1978 .

\section{Cattle Days on the Riparian Zone}

Number of cattle and the duration of time spent on the riparian zone are important factors in assessing the net impact of cattle on that zone. A characteristic pattern of livestock time spent on the riparian zone was evident. The proportion of cattle days compared to the proportion of grazing time by period revealed that, in 1977 , the percentage of cattle days spent on the riparian zone in early periods was significantly larger than the percentage of time by period (Table 1). The percentage of cattle days spent on the riparian zone reflected a managerial influence on cattle movements. Cattle were turned on at a single gate where the road funneled the cattle onto the riparian zone. Therefore, nearly the whole herd was on the riparian zone at the initiation of the grazing season.

They remained on the riparian zone 7 to 10 days with some animals progressively dispersing onto other areas. Cattle numbers on the riparian area stabilized after about 21 days at 35 to $40 \%$ of the herd with other cattle moving back and forth between upland types and the riparian zone. This movement was more prevalent in 1977 primarily because of limited water availability away from the riparian area, due to limited precipitation. An important factor to note is that the livestock dispersed before the forage became limiting.

The trend in percentage of animals per week was the same for both years, showing progressively fewer animal days per week through the sixth week. However, the last week reflected an increase in animal days on the riparian zone. Number of cattle days on the riparian zone were based on actual sightings. The portion of the cattle which moved between the uplands and the riparian zone may not have been included in the observation data representing some error. The observed number of animal days on the riparian zone could account for only $71 \%$ and $81 \%$ of the vegetation disappearance for 1977 and 1978 respectively, calculated from average daily consumption of $11 \mathrm{~kg}$ dry matter.

\section{Discussion}

Physical limitations on cattle movements imposed by slope and management practice of turning the cattle in at one point contributed to concentrating the cattle on the riparian zone early in the grazing season. The utilization resulting from this action represented a large proportion of the total season use on the riparian vegetation (Table 1). However, the percentage of total forage removed was significantly greater than the percentage of animal numbers for that period. Johnstone-Wallace and Kennedy (1944) reported intake values of $32 \mathrm{lb} /$ day $(14.6 \mathrm{~kg} /$ day) dry matter for cattle using bluegrass when forage was highly available. They, as well as Hodgson and Wilkinson (1968), reported marked declines in forage intake when herbage availability per unit area decreased, even though total forage available was not limiting. Similar patterns of herbage intake displayed by the cattle on the riparian zone combined with trampling losses of forage as described by Laycock and Harniss (1974) could explain a substantial portion of the disparity between percentage forage consumed and percentage of cattle days spent grazing.

Cattle using the riparian zone showed little inclination to use the south slopes bordering that area through most of the grazing season even though utilization on riparian vegetation progressively reduced available forage.

During the last 2 weeks of the grazing season observation of cattle indicated that there was increased use on the associated south slopes. This probably occurred because of a combination of factors. During this period of both years a substantial amount of rainfall occurred, which is known to increase the palatability of cured vegetation (Springfield and Reynolds 1951). Nighttime low temperatures were dropping to -2 to $8^{\circ} \mathrm{C}$ on the riparian zone and a noticeable cold air accumulation could be felt in the early evenings and early mornings. Behavioral scientists have indicated that animals tend to avoid cold pockets in bedding and grazing (Arnold and Dudzinski 1978). Therefore, it seems most plausible to think that the use on the slopes was due to differential palatability and microclimate-induced animal behavior response.

Kentucky bluegrass was the dominant grass species on the riparian zone and probably exerted major control over the relative stability of these plant communities. Grazing on Kentucky bluegrass was at a level which has been demonstrated to have small impacts on vigor and cover. Etter (1951) found bluegrass clipped to 1 inch, seasonlong for 4 years, did not reduce numbers of shoots or rhizomes. However, some reduction in yield was shown. Volland (1978) reported that production of a previously continuously grazed riparian zone increased significantly for 6 years after deferment was initiated. After that time, production decreased progressively. At the end of 11 years of deferment, the ungrazed area had lower production and root mass than the adjacent continuously grazed area. Grazing on the riparian zone reduced the height of Kentucky bluegrass to about 1 inch after 4 weeks and that level was maintained for the duration of the grazing season. It seems unlikely, based on the growth habit and physiology of bluegrass, that cattle grazing bluegrass meadows over a 6-week time span from early to mid-summer would cause sufficient impact to reduce the cover of Kentucky bluegrass. The impact of grazing on the other herbaceous vegetation on the same unit in the year previous to the study on the riparian zone indicated that use was much lower on the herbaceous component when the unit was deferred until mid-August. This phenomenon was probably produced by a combination of low relative palatability and cold air accumulation on the meadows. Apparently, the utilization of herbaceous components in the riparian zone can be manipulated by changing season of use.

The impact of grazing on shrubs was more difficult to assess because of the variability of shrub utilization caused by year effect and lack of information on the response of riparian shrubs to summer utilization. Aldous (1952) published information reporting the response of shrubs to degree of winter utilization. Those results indicated that willow responded to $50 \%$ annual utilization of leader material with increases in production of 248,118 , and $164 \%$ in successive years. With this in mind, willow was within a limit of utilization in 1977 and 1978 that should allow for increases in production (Table 3 ). Red-osier dogwood was used relatively heavily in 1977. However, the height regrowth, leader lengths and numbers were exceptionally large the following year. Utilization on dogwood was light in 1978. Aldous (1952) indicated that redosier dogwood could not withstand $90 \%$ annual utilization for a prolonged period over several years, but $25 \%$ annual utilization had not negative impacts over years. Therefore, dogwood on this area should tolerate use 1 year at moderate levels followed by a year of light utilization. Insufficient evidence is available from the 
literature to predict the influence of grazing on other shrubs. Observations indicated the dry year induced livestock to use browse more than they did in a more mesic year. Cattle grazing this unit in 1976 when it was deferred until fall utilized browse heavily on the riparian area, even though utilization of herbaceous vegetation was low. Apparently, season of use and degree of shrub utilization were related to palatability of the available herbaceous vegetation and perhaps to change in the palatability of the browse itself.

\section{Conclusions}

Combinations of factors caused cattle to concentrate within the riparian zone early in the grazing season and to use a relatively high proportion of the vegetation during the first 4 weeks of the grazing period. After this period cattle numbers on the riparian zone stabilized and remained consistent until shortly before a pasture change.

Pattern of shrub utilization was related to relative vegetation palatability on the riparian zone and adjacent areas and showed a great deal of variation according to years and season of use. Shrub use tended to increase as the season progressed. Shrub utilization was lowest when herbaceous vegetation was lush and very palatable and greatest when herbaceous vegetation was coarse and mature.

The influence of grazing on Kentucky bluegrass was apparently minimal as far as maintenance of cover and plant vigor was concerned. Additionally, grazing pressure apparently was not depressing yield. The greatest quandary is the problem of maximizing shrub growth and optimizing herbaceous plant yield. Seemingly, the management requirement which would benefit shrubs most, grazing when the herbaceous component is lush, would shift utilization away from shrubs. However, this action could have the greatest potential for damaging the herbaceous component. Conversely, late season grazing minimizes impact on herbaceous components but increases shrub utilization.

\section{Literature Cited}

Aldous, S.E. 1952. Deer browse clipping study in the Lake States Region. J. Wildl. Manage. 16:401-409.

Ames, C.R. 1977. Wildlife conflicts in riparian management: grazing. In: Importance, Preservation and Management of Riparian Habitat: A Symposium. U.S. Dep. Agr. Forest Serv. Gen. Tech. Rep. RM-43:49-51. Arnold, G.W., and M.L. Dudzinski. 1978. Ethology of free-ranging domestic animals. Elsevier Sci. Pub. Co. N.Y. 198 p.
Bolt, C.E., D.W. Uresk, and K.E. Severson. 1978. Riparian woodlands in jeopardy in Northern High Plains. In: Strategies for Protection and Managment of Floodplain Wetlands and Other Riparian Ecosystems. U.S. Dep. Agr. Forest Serv. Gen. Tech. Rep. WO-12:184-189.

Branson, F.A. 1956. Quantitative effects of clipping treatments on five range grasses. J. Range Manage. 9:86-88.

Cook, C.W. 1966. Factors affecting utilization of mountain slopes by cattle. J. Range Manage. 19:200-204.

Donart, G.B. 1969. Carbohydrate reserves of six mountain range plants as related to growth. J. Range Manage. 22:411-415.

Etter, A.G. 1951. Excerpts from How Kentucky Bluegrass Grows. Annals of the Missouri Bot. Garden. 38:352-369.

Federer, C.A., G.H. Tenpas, D.R. Schmidt, and C.B. Tanner. 1961. Pasture soil compaction by animal traffic. Agron. J. 53:53-54.

Handl, W.P., and L.R. Rittenhouse. 1972. Herbage yield and intake of grazing steers. Amer. Soc. Anim. Sci. West. Sec. Proc. 23:197-200.

Horton, J.S., and C.J. Campbell. 1974. Management of phreatophyte and riparian vegetation for maximum multiple use values. U.S. Dep. Agr. Forest Serv. Res. Pap. RM-117. 23 p.

Hubbard, J.P. 1977. Importance of riparian ecosystems: Biotic considerations. In: Importance, Preservation and Management of Riparian Habitat: A Symposium. U.S. Dep. Agr. Forest Serv. Gen. Tech. Rep. RM-43. $217 \mathrm{p}$.

Johnstone-Wallace, D.B., and K. Kennedy. 1944. Grazing management practices and their relationship to the behavior and grazing habits of cattle. J. Agr. Sci. 34:190-197.

Laycock, W.A., and R.O. Harniss. 1974. Trampling damage on native forb-grass range grazed by sheep and cattle. In: Grassland Utilization Sec. XII Int. Grassland Congress, Russia. p. 349-354.

Mueggler, W.F. 1967. Response of mountain grassland vegetation to clipping in southwestern Montana. Ecology 48:942-949.

Orr, H.K. 1960. Soil porosity and bulk density on grazed and protected Kentucky bluegrass range in the Black Hills. J. Range Manage. 13:80-86.

Phillips, T.A. 1965. The influence of slope gradient, distance from water and other factors on livestock distribution on National Forest cattle allotments of the Intermountain Region. U.S. Dep. Agr. Forest Serv. Intmtn. Forest and Range Exp. Sta. Range Impr. Notes. 10:9-19.

Pickford, G.D., and E.H. Reld. 1948. Forage utilization on summer cattle ranges in Eastern Oregon. U.S. Dep. Agr. Circ. 796. 27 p.

Pond, F.W. 1961. Effect of three intensities of clipping on the density and production of meadow vegetation. J. Range Manage. 14:34-38.

Steel, R.G.D., and J.H. Torrie. 1960. Principles and Procedures of Statistics. McGraw-Hill Book Co. New York. 481 p.

Volland, L.A. 1978. Trends in standing crop and species composition of a rested Kentucky bluegrass meadow over an 11 year period. In: D.N. Hyder (Ed.) Proc. 1st Int. Rangeland Congr., Denver, Colo. 1978. p. 526-529.

Wilm, H.G., D.F. Costello, and G.E. Klipple. 1944. Estimating forage yield by the double-sampling method. J. Amer. Soc. Agron. 36:194-203. 